\title{
THE EFFECT OF DISSOLVED ORGANIC CARBON ON PELAGIAL AND NEAR-SEDIMENT WATER TRAITS IN LAKES
}

\author{
KRZYSZTOF BANAŚ \\ University of Gdańsk, Department of Plant Ecology \\ Al. Legionów 9, 80-441 Gdańsk, Poland \\ e-mail: dokkrb@univ.gda.pl
}

(Received: April 2, 2004. Accepted: December 1, 2004)

\begin{abstract}
The effect of dissolved organic carbon (DOC) on the environmental conditions of macrophytes has been studied in 35 lakes divided into soft- and hardwater: oligohumic $\left(<4.0 \mathrm{mg} \mathrm{C} \mathrm{dm}^{-3}\right), \alpha$-mesohumic (4.0-8.0 $\left.\mathrm{mg} \mathrm{C} \mathrm{dm}^{-3}\right), \beta-$ -mesohumic (8.1-16.0 $\left.\mathrm{mg} \mathrm{C} \mathrm{dm}^{-3}\right)$ and polihumic (>16.0 $\left.\mathrm{mg} \mathrm{C} \mathrm{dm}^{-3}\right)$.

The optimum environmental conditions for macrophytes have been found in oligohumic lakes, characterised by low water colour and its good transparency. In soft- and hardwater lakes increasing concentration of DOC is accompanied with an increase in the colour $(\mathrm{r}=0.95)$, while the visibility decreases. With increasing DOC in the near-sediment layer the $\mathrm{pH}$ values decrease while the concentration of nitrogen increases and the concentration of phosphorus slightly increases. In hardwater lakes with increasing DOC concentration, the redox potential, conductivity, total hardness and calcium concentration in the near-sediment water decrease, whereas the content of $\mathrm{CO}_{2}$ remains at a very low level.
\end{abstract}

KEY WORDS: soft- and hardwater lakes, environmental conditions, pelagial, near-sediment water, DOC.

\section{INTRODUCTION}

Many lakes are connected into systems of drainage ditches and channels filled with waters rich in humus substances from the drained peat-bogs. Through them large amounts of dissolved organic carbon (DOC) enter the lakes (of different genesis, trophy and direction of development) and permanently change the environmental conditions in them. This influx of DOC leads, consequently, to significant changes in the lake ecosystem (Górniak 1996), including changes in the flora and vegetation (Bociag 2000; Szmeja 2000).

With increasing content of allochtonous carbon compounds, especially humic acids, in the lakes, the $\mathrm{pH}$ values of water and bottom sediments decrease, the rate of organic matter decomposition decreases, the redox potential of the sediment increases and anaerobiosis becomes more enhanced (Lampert and Sommer 1996). These changes disturb the circulation of biogenic elements (Grahn 1985), causing the plants exchange according to their demand on inorganic carbon (DIC) including the species $\mathrm{CO}_{2}$ and $\mathrm{HCO}_{3}^{-}$ (Sand-Jensen 1989), and the structure and species composition of phytocenoses change (Szmeja 1992). The acidic bottom sediments restrict the appearance of many aquatic plants, leading to changes in their population structure (Roelofs 1983; Grahn 1985; Arts 1987; Szmeja 1994a, b, c) and initiate the exchange of the basiphilous and neutro- philous species by acidophilous ones, mainly bryophytes (Szmeja 2000; Bociąg 2000).

The last two decades witnessed great progress in investigation of phenomena and physico-chemical processes involving organic carbon from humic substances (Stevenson 1982; Långvik et al. 1994; Morris and Hargreaves 1997; Hessen and Tranvik 1998; Keskitalok and Eloranta 1999; Artinger et al. 2000; Lehtonen et al. 2000). This recent accumulation of information makes a promising background to study the effect of DOC coming from the drainage of peat-bogs on the environmental conditions in the lakes. The excess of DOC in water and bottom sediments of the lakes leads to a decrease in the primary production, depauperisation of the diversity of flora and disappearance of the zonal arrangement of the vegetation (Bociąg 2000; Bociąg and Szmeja 2001; Szmeja 2000). However, it is still unknown which particular cause effected by DOC increase is the main reason for the plant withdrawal from humic lakes.

The following hypotheses have been accepted in the study:

1. The hard- and softwater lakes are equally susceptible to the effect of DOC.

2. The scale of transformations in the water environment is a function of DOC concentration.

3. The susceptibility of the environmental conditions to changes induced by increased concentration of DOC depends on the features of the limnic environment. 
The subjects of the study were physical and chemical changes of the pelagial and near-sediment water in the lakes supplied with rich in organic compounds waters coming from fen and peat-bog.

\section{MATERIAL AND METHODS}

\section{Sampling}

The study was performed in the years 1997-2003, in softand hardwater lakes in NW Poland. On the basis of the DOC concentration in water the following division of the lakes was assumed:

1) oligohumic $\left(<4.0 \mathrm{mg} \mathrm{C}_{\mathrm{DOC}} \mathrm{dm}^{-3}\right)$,

2) $\alpha$-mesohumic $\left(4.0-8,0 \mathrm{mg} \mathrm{C}_{\mathrm{DOC}} \mathrm{dm}^{-3}\right)$,

3) $\beta$-mesohumic $\left(8,1-16,0 \mathrm{mg} \mathrm{C}_{\text {DOC }} \mathrm{dm}^{-3}\right)$,

4) polihumic ( $>16,0 \mathrm{mg} \mathrm{C}_{\text {DOC }} \mathrm{dm}^{-3}$ ).

Analyses were performed for 35 lakes, including 15 oligohumic, $7 \alpha$-mesohumic, $7 \beta$-mesohumic and 6 polihumic. In the oligohumic lakes DOC is of autochtonous origin, occurs in minimum concentrations and does not determine the specific character of the environmental conditions, while in the meso- and polihumic lakes these conditions are determined by allochtonous DOC.

The water samples were collected of pelagial at 0.5 $\mathrm{m}$ below the water surface and at $0.5 \mathrm{~m}$ above the bottom in the deepest site of the lake. The samples of near-sediment water were collected immediately above the sediment and from the levels at the depths of $1,2,3 \mathrm{~m}$ etc., from the coat to the deepest limit of plants appearance in the lake. In each zone three subsamples of the near-sediment water of 1 $\mathrm{dm}^{3}$ each were collected and then combined into one sample from a given zone. The environmental conditions were evaluated on the basis of 262 samples of near-sediment water, 35 samples of surface water and 35 ones of water from the deepest sites of the lakes.

\section{Methods of water analysis}

Evaluation of the environmental conditions in pelagial was performed on the basis of the following parameters: distribution of oxygen and temperature in the profile by an oxygen meter OXI 96 with EOT 196 electrode, visibility distance by the Secchi disk, $\mathrm{pH}$ value, conductivity, colour, total hardness, the contents of calcium, Kjeldahl nitrogen $\left(\mathrm{N}_{\mathrm{Kjel}}\right)$, total phosphorus (TP) and dissolved organic carbon (DOC). The near-sediment water samples were characterised by $\mathrm{pH}$ value, conductivity, concentrations of calcium,
$\mathrm{N}_{\text {Kjel. }}$, TP and $\mathrm{CO}_{2}$. The conduction was measured by a conductometer LF-95/SET with a four-electrode TetraCon 96 WTW system, pH and the redox potential were determined by a pH-meter SET-1, with a combined EPH-11 type electrode and a Mettier Toledo Pt 4805-57/120 electrode. Free $\mathrm{CO}_{2}$ was determined by titration of $100 \mathrm{ml}$ of water with carbonate free $0.05 \mathrm{~N} \mathrm{NaOH}$ solution against phenolophtaleine as an indicator. The content of TP was found by a molybdate colorimetric method with ascorbic acid as a reductor (Hermanowicz et al. 1999). Total Kjeldahl nitrogen was determined after mineralisation by the method of nesslerization (Hermanowicz et al. 1999). The content of DOC was determined by spectrophotometric methods (Moore 1985, 1987; Collier 1987; Górniak 1995). The absorbency of the filtered off samples was measured on an UV-VIS spectrophotometer (Shimadzu UV-1202) at $\lambda=330 \mathrm{~nm}$. The concentration of DOC was read out from the calibration curve determined as the dependence of absorbency $\left(\mathrm{A}_{330}\right)$ on DOC concentration measured by a Multi C Analyser. The colour of water samples was assessed by comparison to a scale of chromium-cobalt standards according to Hermanowicz et al. (1999).

\section{Statistical analysis methods}

The arithmetic mean (x), standard deviation (s.d.), (min.max.) range and median (Me) were calculated (Hays 1988). Statistical inference was carried out at a $5 \%$ error risk. The statistical significance of differences was tested by a single-factor variance analysis ANOVA with a Tukey test (Milliken and Johnson 1984; Hays 1988). The co-dependence in the pairs of the water parameters was determined for the lakes from oligo- to polihumic by the correlation analysis (Oktaba 1980; Łomnicki 1999).

\section{RESULTS}

\section{Environmental conditions in softwater lakes}

In oligohumic lakes the bulk water is colourless or weakly coloured $\left(0-17 \mathrm{mg} \mathrm{Pt} \mathrm{dm}^{-3} ; \mathrm{Me}=4.5\right)$ and transparent (visibility distance $5.6 \pm 2.1 \mathrm{~m} ; \mathrm{Me}=5.0$; Table 1 ). The latter feature follows from a low concentration of dissolved organic carbon $\left(2.9 \pm 1.2 \mathrm{mg} \mathrm{C}_{\mathrm{DOC}} \mathrm{dm}^{-3} ; \mathrm{Me}=2.5\right)$. The water is characterised by low total hardness $\left(7.4 \pm 4.9 \mathrm{mg} \mathrm{CaO} \mathrm{dm}^{-3}\right.$; $\mathrm{Me}=5.7)$ and low concentration of calcium $(3.9 \pm 2.9 \mathrm{mg} \mathrm{Ca}$ $\mathrm{dm}^{-3} ; \mathrm{Me}=2.9$; Table 1).

The near-sediment water has a $\mathrm{pH}$ from 4.0 to 7.5 $(\mathrm{Me}=5.3)$ and a very low electrolytic conductivity (48.1 \pm

TABLE 1. Physical and chemical properties of near-sediment water and pelagial (bold) in softwater lakes.

\begin{tabular}{|c|c|c|c|c|c|c|c|c|c|c|c|c|}
\hline \multirow[t]{2}{*}{ Lake types: } & \multicolumn{3}{|c|}{ Oligohumic } & \multicolumn{3}{|c|}{$\alpha$-mesohumic } & \multicolumn{3}{|c|}{$\beta$-mesohumic } & \multicolumn{3}{|c|}{ Polihumic } \\
\hline & $\min -\max$ & $\mathrm{x} \pm \mathrm{sd}$ & $\mathrm{Me}$ & $\min -\max$ & $\mathrm{x} \pm \mathrm{sd}$ & $\mathrm{Me}$ & $\min -\max$ & $\mathrm{x} \pm \mathrm{sd}$ & $\mathrm{Me}$ & $\min -\max$ & $\mathrm{x} \pm \mathrm{sd}$ & $\mathrm{Me}$ \\
\hline $\mathrm{pH}$ & $4.0-7.5$ & $5.5 \pm 1.0$ & 5.3 & $4.2-7.6$ & $5.5 \pm 1.2$ & 5.1 & $4.3-7.0$ & $5.6 \pm 0.9$ & 5.4 & $3.9-6.6$ & $4.8 \pm 0.8$ & 4.6 \\
\hline Conductivity $\left[\mu \mathrm{S} \mathrm{cm}^{-1}\right]$ & $26-82$ & $48.1 \pm 15.6$ & 45.5 & $36.1-81$ & $53.8 \pm 15.9$ & 48.5 & $40.0-96.7$ & $59.6 \pm 16.1$ & 55.0 & $47.7-72.4$ & $63.3 \pm 13.8$ & 57.0 \\
\hline $\mathrm{Eh}[\mathrm{mV}]$ & $169-365$ & $281 \pm 50$ & 279 & $17-382$ & $296 \pm 54$ & 300 & $-210-383$ & $219 \pm 146$ & 220 & $31-466$ & $232 \pm 133$ & 290 \\
\hline $\mathrm{TP}\left[\mathrm{mg} \mathrm{P} \mathrm{dm}^{-3}\right]$ & $0.05-0.23$ & $0.1 \pm 0.04$ & 0.11 & $0.07-0.9$ & $0.1 \pm 0.2$ & 0.1 & $0.07-0.2$ & $0.1 \pm 0.04$ & 0.12 & $0.09-0.22$ & $0.1 \pm 0.03$ & 0.13 \\
\hline $\mathrm{N}_{\text {Kjel. }}\left[\mathrm{mg} \mathrm{N} \mathrm{dm}^{-3}\right]$ & $0.5-3.0$ & $1.3 \pm 0.5$ & 1.1 & $0.9-3.1$ & $2.1 \pm 0.7$ & 2.2 & $1.4-6.0$ & $3.4 \pm 1.2$ & 3.5 & 1.3-7.2 & $4.2 \pm 1.6$ & 4.5 \\
\hline $\mathrm{CO}_{2}\left[\mathrm{mg} \mathrm{dm}^{-3}\right]$ & $1.1-16.9$ & $4.6 \pm 3.2$ & 3.7 & $3.7-9.2$ & $7.0 \pm 2.3$ & 8.1 & $2.2-32.5$ & $11.4 \pm 12.5$ & 5.0 & 4.4 & 4.4 & 4.4 \\
\hline Colour [mg Pt dm ${ }^{-3}$ ] & 0-17 & $5 \pm 5$ & 4.5 & $13-43$ & $25 \pm 13$ & 22 & $44-150$ & $83 \pm 43$ & 68 & $150-600$ & $348 \pm 189$ & 320 \\
\hline Visibility [m] & $4-11$ & $5.6 \pm 2.1$ & 5 & $1.5-3.5$ & $2.5 \pm 0.9$ & 2.6 & $1-2$ & $1.4 \pm 0.4$ & 1.4 & $0.5-1$ & $0.6 \pm 0.2$ & 0.5 \\
\hline $\mathrm{DOC}\left[\mathrm{mg} \mathrm{C} \mathrm{dm} \mathbf{~ d m}^{-3}\right]$ & 1.8-5.6 & $2.9 \pm 1.2$ & 2.5 & $4.7-5.5$ & $4.9 \pm 0.4$ & 4.8 & 8.0-14.3 & $9.6 \pm 2.4$ & 8.8 & 18.8-44.0 & $32.4 \pm 10.5$ & 33.3 \\
\hline $\mathrm{Ca}\left[\mathrm{mg} \mathrm{dm}^{-3}\right]$ & 1.4-11.2 & $3.9 \pm 2.9$ & 2.9 & $1.5-8.7$ & $4.6 \pm 3.2$ & 4.3 & $1.2-8.5$ & $4.5 \pm 2.5$ & 4.1 & 2.3-11.3 & $6.7 \pm 4.3$ & 6.5 \\
\hline Hardness [ $\left.\mathrm{mg} \mathrm{CaO} \mathrm{dm}^{-3}\right]$ & 2.7-17.9 & $7.4 \pm 4.9$ & 5.7 & $3.4-15.5$ & $8.5 \pm 5.3$ & 7.5 & $2.5-13.2$ & $7.7 \pm 3.5$ & 7.5 & $3.8-15.9$ & $10.3 \pm 5.1$ & 10.7 \\
\hline
\end{tabular}


$\left.\pm 15.6 \mu \mathrm{S} \mathrm{cm} \mathrm{cm}^{-1} ; \mathrm{Me}=45.5\right)$. The contents of $\mathrm{TP}(0.1 \pm 0.04$ $\left.\mathrm{mg} \mathrm{P} \mathrm{dm}{ }^{-3} ; \mathrm{Me}=0.11\right)$ and $\mathrm{N}_{\text {Kjel. }}\left(1.3 \pm 0.5 \mathrm{mg} \mathrm{N} \mathrm{dm}^{-3}\right.$; $\mathrm{Me}=1.1)$ are low. In this water the oxidation reactions prevail (Eh $281 \pm 50 \mathrm{mV}$; Me=279) it shows a high concentration of oxygen $\left(6.8-10.2 \mathrm{mg} \mathrm{O}_{2} \mathrm{dm}^{-3}\right)$ but low of $\mathrm{CO}_{2}$ (4.6 $\pm 3.2 \mathrm{mg} \mathrm{dm}^{-3} ; \mathrm{Me}=3.7$; Table 1).

In $\alpha$-mesohumic lakes the bulk water has more colour $\left(25 \pm 13 \mathrm{mg} \mathrm{Pt} \mathrm{dm}{ }^{-3} ; \mathrm{Me}=22\right)$ and is less transparent (visibility distance $2.5 \pm 0.9 \mathrm{~m} ; \mathrm{Me}=2.6$ ). The differences are statistically significant for the colour $\mathrm{p}<0.001$, for the visibility $p=0.01$. The yellow colour of the water and its considerable turbidity are a consequence of almost twice higher concentration of DOC $\left(4.9 \pm 0.4 \mathrm{mg} \mathrm{C}_{\text {DOC }} \mathrm{dm}^{-3} ; \mathrm{Me}=4.8\right.$; $\mathrm{p}=0.006)$. The total hardness $\left(8.5 \pm 5.3 \mathrm{mg} \mathrm{CaO} \mathrm{dm}^{-3}\right.$; $\mathrm{Me}=7.5)$ and calcium concentration $\left(4.6 \pm 3.2 \mathrm{mg} \mathrm{Ca} \mathrm{dm}^{-3}\right.$; $\mathrm{Me}=4.3$; Table 1) are still low.

The near-sediment water in the littoral has a similar $\mathrm{pH}$ as in oligohumic lakes (4.2-7.6; $\mathrm{Me}=5.1)$ and its electrolytic conductivity is only slightly higher $\left(53.8 \pm 15.9 \mu \mathrm{S} \mathrm{cm}^{-1}\right.$; $\mathrm{Me}=48.5)$. The content of TP is similar $\left(0.1 \pm 0.2 \mathrm{mg} \mathrm{dm}^{-3}\right.$; $\mathrm{Me}=0.1$ ), while the content of $\mathrm{N}_{\mathrm{Kjel}}$ is almost twice higher (2.1 $\left.\pm 0.7 \mathrm{mg} \mathrm{N} \mathrm{dm}^{-3} ; \mathrm{Me}=2.2\right)$. In the near-sediment water the oxidation reactions dominate (Eh 296 $554 \mathrm{mV}$; $\mathrm{Me}=300)$, the oxygen concentration is high $\left(4.3-9.6 \mathrm{mg} \mathrm{O}_{2}\right.$ $\left.\mathrm{dm}^{-3}\right)$, and that of $\mathrm{CO}_{2}$ low $\left(7.0 \pm 2.3 \mathrm{mg} \mathrm{dm}^{-3}\right.$; $\mathrm{Me}=8.1$; Table 1).

The differences between the water parameters in oligoand $\alpha$-mesohumic lakes in $\mathrm{N}_{\mathrm{Kjel}}$. concentration $(\mathrm{p}<0.001)$, DOC $(p=0.001)$, visibility distance $(p=0.01)$ and colour $(p<0.001)$ are statistically significant.

In $\beta$-mesohumic lakes the bulk water has a more intense colour than that of $\alpha$-mesohumic lakes $\left(83 \pm 43 \mathrm{mg} \mathrm{Pt} \mathrm{dm}^{-3}\right.$; $\mathrm{Me}=68$ ) and is less transparent (visibility distance 1.4 \pm 0.4 $\mathrm{m} ; \mathrm{Me}=1.4$ ). The brown colour of water is a consequence of a twice higher concentration of DOC $\left(9.6 \pm 2.4 \mathrm{mg} \mathrm{C} \mathrm{dm}^{-3}\right.$; $\mathrm{Me}=8.8)$. The total hardness $\left(7.7 \pm 3.5 \mathrm{mg} \mathrm{CaO} \mathrm{dm}^{-3}\right.$; $\mathrm{Me}=7.5)$ and calcium concentration $\left(4.5 \pm 2.5 \mathrm{mg} \mathrm{Ca} \mathrm{dm}^{-3}\right.$; $\mathrm{Me}=4.1$; Table 1) assume similar values.

The near-sediment water has a pH 4.3-7.0 (Me=5.4), and the range of variation of this parameter is slightly smaller than in $\alpha$-mesohumic lakes. Its conductivity $(59.6 \pm 16.1$ $\left.\mu \mathrm{S} \mathrm{cm} \mathrm{cm}^{-1} ; \mathrm{Me}=55.0\right)$ and the content of TP $(0.1 \pm 0.04 \mathrm{mg}$ $\mathrm{dm}^{-3} ; \mathrm{Me}=0.12$ ) are similar, while the content of $\mathrm{N}_{\mathrm{Kjel} .}$ is higher $\left(3.4 \pm 1.2 \mathrm{mg} \mathrm{dm}^{-3} ; \mathrm{Me}=3.5 ; \mathrm{p}<0.001\right)$. In the abovesediment water the oxidation reactions dominate (Eh $219 \pm 146 \mathrm{mV} ; \mathrm{Me}=220$ ), however, because of sometimes met anaerobic conditions (0.1-3.2 $\left.\mathrm{mg} \mathrm{O}_{2} \mathrm{dm}^{-3}\right)$, the redox potential takes also negative values (Eh -210-383 mV), which result in a significant increase in $\mathrm{CO}_{2}$ concentration $\left(11.4 \pm 12.5 \mathrm{mg} \mathrm{dm}^{-3} ; \mathrm{Me}=5.0\right.$; Table 1$)$ in the above-sediment water.

Statistically significant differences between the conditions in $\beta$-mesohumic and $\alpha$-mesohumic lakes occur in the content of $\mathrm{N}_{\text {Kjel. }}(\mathrm{p}<0.001)$, DOC $(\mathrm{p}=0.005)$, colour, visibility $(\mathrm{p}<0.03)$ and redox potential $(\mathrm{p}<0.02)$.

In polihumic lakes the bulk water is usually brown (348 $\left.\pm 189 \mathrm{mg} \mathrm{Pt} \mathrm{dm}^{-3} ; \mathrm{Me}=320\right)$ and turbid (visibility distance $0.6 \pm 0.2 \mathrm{~m} ; \mathrm{Me}=0.5$ ). This very intense colour is a consequence of a much higher concentration of DOC (32.4 $\left.\pm 10.5 \mathrm{mg} \mathrm{C} \mathrm{dm}^{-3} ; \mathrm{Me}=33.3\right)$. The total hardness is higher than in $\beta$-mesohumic lakes $\left(10.3 \pm 5.1 \mathrm{mg} \mathrm{CaO} \mathrm{dm}^{-3}\right.$; $\mathrm{Me}=10.7$ ), but statistically significant is the difference in the calcium concentration - much higher in polihumic lakes $(\mathrm{p}<0.001)$.

The near-sediment water has a $\mathrm{pH}$ ranging from highly acidic to almost neutral (3.9-6.6; $\mathrm{Me}=4.6)$. The range of $\mathrm{pH}$ variability is similar as in $\beta$-mesohumic lakes. The conductivity $(63.3 \pm 13.8 \mu \mathrm{S} \mathrm{cm}-1, \mathrm{Me}=57)$ and the concentration of $\mathrm{N}_{\text {Kjel. }}(\mathrm{p}=0.02)$ are slightly higher. Because the maximum depths of polihumic lakes is relatively small the near-sediment water are well oxidised and the dominant reactions in it are those of oxidation (Eh $232 \pm 133 \mathrm{mV}$; $\mathrm{Me}=290$ ), while the concentration of $\mathrm{CO}_{2}$ is low (Table 1).

The differences between $\beta$-mesohumic and polihumic lakes are statistically significant in the concentration of calcium, $\mathrm{N}_{\text {Kjel. }}$, DOC, $\mathrm{CO}_{2}$, visibility and colour.

\section{Environmental conditions in hardwater lakes}

Pelagial of oligohumic lakes has a light colour $(6-8 \mathrm{mg}$ $\mathrm{Pt} \mathrm{dm}^{-3} ; \mathrm{Me}=7$ ), is transparent (visibility distance $6.2 \pm 1.6$ $\mathrm{m} ; \mathrm{Me}=5.5)$ and has a low concentration of DOC $(4.6 \pm 1.3$ $\left.\mathrm{mg} \mathrm{C}_{\mathrm{DOC}} \mathrm{dm}^{-3} ; \mathrm{Me}=4.4\right)$. It is characterised by a significant total hardness $\left(51.6 \pm 19.3 \mathrm{mg} \mathrm{CaO} \mathrm{dm}^{-3} ; \mathrm{Me}=58.3\right)$, and a high concentration of calcium $\left(31.4 \pm 9.6 \mathrm{mg} \mathrm{Ca} \mathrm{dm}^{-3}\right.$; $\mathrm{Me}=35.5$ ).

The near-sediment water in littoral has $\mathrm{pH}$ varying from neutral to basic $(7.1-8.4 ; \mathrm{Me}=8.0)$, is characterised by high electrolytic conductivity $\left(179 \pm 46.1 \mu \mathrm{S} \mathrm{cm}^{-1} ; \mathrm{Me}=191\right)$, low concentration of TP $\left(0.1 \pm 0.05 \mathrm{mg} \mathrm{dm}^{-3} ; \mathrm{Me}=0.1\right)$ and $\mathrm{N}_{\mathrm{Kjel}}$. $\left(1.0 \pm 0.3 \mathrm{mg} \mathrm{dm}^{-3} ; \mathrm{Me}=1.0\right)$. Because of high concentration of oxygen in water (7.4-9.4 $\mathrm{mg} \mathrm{O}_{2} \mathrm{dm}^{-3}$ ), the oxidation reactions dominate (Eh 214 $\pm 73 \mathrm{mV}$; Table 2).

Pelagial of $\alpha$-mesohumic lakes has a stronger colour $\left(36 \pm 15 \mathrm{mg} \mathrm{Pt} \mathrm{dm}^{-3} ; \mathrm{Me}=37 ; \mathrm{p}=0.03\right)$ than that of oligohumic ones and hence less transparent (visibility distance $1.8 \pm 0.8 \mathrm{~m})$. The darker colour and its grater turbidity are

TABLE 2. Physical and chemical properties of near-sediment water and pelagial (bold) in hardwater lakes.

\begin{tabular}{|c|c|c|c|c|c|c|c|c|c|c|c|c|}
\hline \multirow[t]{2}{*}{ Lake types: } & \multicolumn{3}{|c|}{ Oligohumic } & \multicolumn{3}{|c|}{$\alpha$-mesohumic } & \multicolumn{3}{|c|}{$\beta$-mesohumic } & \multicolumn{3}{|c|}{ Polihumic } \\
\hline & $\min -\max$ & $\mathrm{x} \pm \mathrm{sd}$ & $\mathrm{Me}$ & $\min -\max$ & $\mathrm{x} \pm \mathrm{sd}$ & $\mathrm{Me}$ & $\min -\max$ & $\mathrm{x} \pm \mathrm{sd}$ & $\mathrm{Me}$ & $\min -\max$ & $\mathrm{x} \pm \mathrm{sd}$ & $\mathrm{Me}$ \\
\hline $\mathrm{pH}$ & $7.1-8.4$ & $7.9 \pm 0.4$ & 8.0 & $6.6-7.9$ & $7.5 \pm 0.4$ & 7.6 & $6.2-7.2$ & $6.7 \pm 0.5$ & 6.6 & $6.1-6.6$ & $6.3 \pm 0.2$ & 6.2 \\
\hline Conductivity $\left[\mu \mathrm{S} \mathrm{cm}^{-1}\right]$ & $121-262$ & $179 \pm 46.1$ & 191 & $156-403$ & $250 \pm 102$ & 202 & $157.7-174$ & $164 \pm 7.2$ & 162 & $59.9-112$ & $77.0 \pm 18.2$ & 74.4 \\
\hline $\mathrm{Eh}[\mathrm{mV}]$ & $125-331$ & $214 \pm 73$ & 189 & $13-352$ & $187 \pm 112$ & 149 & $25-76$ & $59 \pm 23$ & 68 & $44-242$ & $129 \pm 101$ & 52 \\
\hline $\mathrm{TP}\left[\mathrm{mg} \mathrm{P} \mathrm{dm}^{-3}\right]$ & $0.06-0.23$ & $0.1 \pm 0.05$ & 0.1 & $0.09-0.3$ & $0.2 \pm 0.06$ & 0.11 & $0.16-0.2$ & $0.2 \pm 0.01$ & 0.18 & $0.08-0.14$ & $0.1 \pm 0.03$ & 0.1 \\
\hline $\mathrm{N}_{\text {Kiel }}\left[\mathrm{mg} \mathrm{N} \mathrm{dm}^{-3}\right]$ & $0.3-1.7$ & $1.0 \pm 0.3$ & 1.0 & $0.6-2.8$ & $1.4 \pm 0.7$ & 1.4 & $1.4-1.9$ & $1.7 \pm 0.2$ & 1.8 & $3.0-4.5$ & $3.8 \pm 0.6$ & 3.6 \\
\hline $\mathrm{CO}_{2}\left[\mathrm{mg} \mathrm{dm}^{-3}\right]$ & $1.8-6.6$ & $3.4 \pm 1.5$ & 2.8 & $2.2-7.3$ & $4.5 \pm 2.0$ & 4.4 & - & - & - & 4.4 & 4.4 & 4.4 \\
\hline Colour $\left[\mathrm{mg} \mathrm{Pt} \mathrm{dm}^{-3}\right]$ & 6-8 & $7 \pm 1$ & 7 & $20-50$ & $36 \pm 15$ & 37 & 96 & $96 \pm 0$ & 96 & $240-360$ & $300 \pm 85$ & 300 \\
\hline Visibility $[\mathrm{m}]$ & $5-8$ & $6.2 \pm 1.6$ & 5.5 & $1.0-2.5$ & $1.8 \pm 0.8$ & 2.0 & 1.5 & $1.5 \pm 0$ & 1.5 & 0.5 & $0.5 \pm 0$ & 0.5 \\
\hline $\mathrm{DOC}\left[\mathrm{mg} \mathrm{C} \mathrm{dm}{ }^{-3}\right]$ & 3.4-6.0 & $4.6 \pm 1.3$ & 4.4 & $5.6-7.2$ & $6.2 \pm 0.9$ & 5.8 & 15.7 & $15.7 \pm 0$ & 15.7 & $23.5-46.1$ & $34.8 \pm 16.0$ & 34.8 \\
\hline $\mathrm{Ca}\left[\mathrm{mg} \mathrm{dm}^{-3}\right]$ & $19.3-41.6$ & $31.4 \pm 9.6$ & 35.5 & 25.9-71 & $43.6 \pm 20.1$ & 34.5 & 47.6 & $47.6 \pm 0$ & 47.6 & $8.4-15.5$ & $12.4 \pm 3.8$ & 12.0 \\
\hline Hardness [mg CaO dm $\left.\mathrm{dm}^{-3}\right]$ & 29.8-66.7 & $51.6 \pm 19.3$ & 58.3 & $39-105$ & $66.9 \pm 34.2$ & 56.4 & 59.4 & $59.4 \pm 0$ & 59.4 & $17.6-24.3$ & $21.0 \pm 4.7$ & 21.0 \\
\hline
\end{tabular}


a consequence of the DOC concentration higher by almost $50 \%\left(6.2 \pm 0.9 \mathrm{mg} \mathrm{dm}^{-3} ; \mathrm{Me}=5.8\right)$. Its total hardness $\left(66.9 \pm 34.2 \mathrm{mg} \mathrm{CaO} \mathrm{dm}^{-3} ; \mathrm{Me}=56.4\right)$, the concentration of calcium $\left(43.6 \pm 20.1 \mathrm{mg} \mathrm{Ca} \mathrm{dm}^{-3} ; \mathrm{Me}=34.5 ; \mathrm{p}=0.007\right)$ is very high (Table 2 ).

The near-sediment water has a $\mathrm{pH}$ lower than in oligohumic lakes $(\mathrm{p}=0.004)$, varying from slightly acidic to weakly basic (6.6-7.9; $\mathrm{Me}=7.6$ ), higher electrolytic conductivity $\left(250 \pm 102 \mu \mathrm{S} \mathrm{cm}^{-1} ; \mathrm{Me}=202 ; \mathrm{p}=0.002\right)$, and Kjeldahl nitrogen concentration $(\mathrm{p}=0.006)$, while a similar TP concentration. It has slightly higher concentration of $\mathrm{CO}_{2}(4.5 \pm 2.0$ $\left.\mathrm{mg} \mathrm{dm}{ }^{-3} ; \mathrm{Me}=4.4\right)$, a lower redox potential, however, the oxidation reactions are still dominant (Eh $187 \pm 112 \mathrm{mV}$; $\mathrm{Me}=149$ ).

Pelagial of $\beta$-mesohumic lakes contains much more DOC than that of á-mesohumic ones $\left(15.7 \mathrm{mg} \mathrm{C}_{\mathrm{DOC}} \mathrm{dm}^{-3}\right.$; $\mathrm{p}=0.01)$, so its colour is stronger $\left(96 \mathrm{mg} \mathrm{Pt} \mathrm{dm}^{-3}\right)$, tending to dark-brown and its visibility distance shorter $(1.5 \mathrm{~m})$. The concentration of calcium is the same.

The near-sediment water has a low $\mathrm{pH}(\mathrm{p}=0.004)$ and much lower conductivity $\left(164 \pm 7.2 \mu \mathrm{S} \mathrm{cm}{ }^{-1}\right.$; Me=162). Because of the relatively high content of oxygen the oxidation processes dominate, but the redox potential is much lower $(\mathrm{p}=0.04)$.

Pelagial of polihumic lakes is dark brown $(300 \pm 85 \mathrm{mg}$ $\mathrm{Pt} \mathrm{dm}{ }^{-3} ; \mathrm{Me}=300$ ), and the visibility distance is only $0.5 \mathrm{~m}$. This strong colour is a consequence of the DOC concentration over twice greater than in $\beta$-mesohumic lakes (34.8 $\left.\pm 16.0 \mathrm{mg} \mathrm{C} \mathrm{dm}^{-3} ; \mathrm{Me}=34.8 ; \mathrm{p}<0.001\right)$. Its total hardness is lower than that in $\beta$-mesohumic lakes $(21.0 \pm 4.7 \mathrm{mg}$ $\mathrm{CaO} \mathrm{dm}^{-3} ; \mathrm{Me}=21.0$; Table 2).

The near-sediment water in littoral is characterised by slightly acidic $\mathrm{pH}(6.1-6.6 ; \mathrm{Me}=6.2)$, lower conductivity (77.0 $\left.\pm 18.2 \mu \mathrm{S} \mathrm{cm}^{-1} ; \mathrm{Me}=74.4\right)$, lower concentrations of calcium (12.4 $\left.\pm 3.8 \mathrm{mg} \mathrm{Ca} \mathrm{dm}^{-3} ; \mathrm{Me}=12.0 ; \mathrm{p}=0.009\right)$ and TP $\left(0.1 \pm 0.03 \mathrm{mg} \mathrm{dm}^{-3} ; \mathrm{Me}=0.1\right)$, while higher that of $\mathrm{N}_{\mathrm{Kjel}}$. $\left(3.8 \pm 0.6 \mathrm{mg} \mathrm{dm}^{-3} ; \mathrm{Me}=3.6 ; \mathrm{p}<0.001\right)$. It is relatively well oxidised so the oxidation reactions are dominant (Eh $129 \pm 101 \mathrm{mV} ; \mathrm{Me}=52)$, and the content of $\mathrm{CO}_{2}$ is low $(\mathrm{Ta}-$ ble 2).

With increasing DOC concentration in lakes' pelagial its colour increases and the visibility distance decreases. The total hardness of softwater lakes does not change, whereas, the total hardness of hardwater lakes slightly increases in mesohumic lakes but in polihumic it decreases almost to the value typical of softwater lakes. With increasing DOC concentration in near-sediment water in soft- and hardwater lakes, the value of $\mathrm{pH}$ decreases, and the decrease is more pronounced in the hardwater ones. Increasing DOC concentration has been also found to be accompanied by increasing concentrations of nitrogen and phosphorus (slight), the changes are greater in softwater lakes. In hardwater lakes the redox potential of the near-sediment water, its conductivity, calcium concentration decrease with growing content of DOC, while the content of $\mathrm{CO}_{2}$ remains at a very low level. The environmental conditions optimum for macrophytes have been found in oligohumic lakes characterised by low water colour and its good transparency. The main reason for the vegetation withdrawal from humic lakes is most probably restricted light accessibility caused by high colour and turbidity of their water rich in allochtonous DOC.

\section{Correlation of environmental features of the lakes}

Analysis of correlation of selected pairs of water characterising parameters has shown that only a few of them are strongly correlated $(r>0.5)$. Namely, strong correlations have been found between $\mathrm{pH}$ and conductivity, redox potential, total hardness and calcium concentration (Fig. 1). Moreover, total hardness shows strong positive correlations with conductivity and calcium concentration and negative correlations with visibility distance and redox potential. A significant correlation has been found between the calcium concentration and conductivity.

With increasing DOC concentration the colour of the water gets stronger $(\mathrm{r}=0.95 ; \mathrm{p}<0.001)$, and its visibility distance decreases $(\mathrm{r}=-0.6)$ (the decrease is abrupt even at a low concentration of DOC) as $\mathrm{y}=5.3 \mathrm{x}^{-0.7}$. Above the DOC concentration of $14 \mathrm{mg} \mathrm{C}_{\mathrm{DOC}} \mathrm{dm}^{-3}$ the visibility distance does not decrease any further and remains equal $0.5 \mathrm{~m}$ (Fig. 2). A strong positive correlation has been found between the concentrations of $\mathrm{N}_{\mathrm{Kjel}}$. and DOC ( $\left.\mathrm{r}=0.7\right)$, although the scatter of values in this correlation is significant, which most probably follows from different trophy and primary production of the lakes studied.

The correlations established for softwater lakes are stronger than those in hardwater ones, in the former strong correlations have been found between the DOC concentration and the water colour, visibility distance and $\mathrm{N}_{\mathrm{Kjel}}$ concentration, while in the latter - only between DOC concentration and the water colour $(\mathrm{r}=0.7)$.

\section{DISCUSSION}

The environmental conditions in the lakes have been determined by the presence of allochtonous DOC coming from humic substances. In Pomerania there are many lakes with dark brown water (Banaś 1999, 2002; Banaś and Gos 2000; Gos et al. 1998), similarly as in many lakes of the northern hemisphere (Oliver et al. 1983; Laaksonen and Malin 1984; Rogalla 1986; Forsberg 1992; Jonsson A. and Jonsson M. 1997). The water colour is a result of accumulation of autochthonous and allochtonous humic substances. In the lakes the dominant are allochtonous carbon compounds (Tipping et al. 1988; Yan et al. 1991), originating from the catchment area (Schindler et al. 1992; Kaplan and Newbold 1993). Hence, there is a strong correlation between the DOC concentration and the water colour (Fig. 2). Low DOC concentration is characteristic of almost colourless water of oligohumic lakes, while high - of dark brown colour of polihumic lakes (Tables 1,2). In some lakes the DOC concentration may

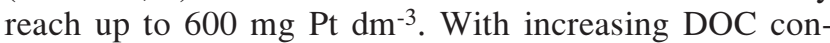
tent the visibility distance strongly decreases. This decrease is rapid already at low DOC concentrations, and then above that of $14 \mathrm{mg} \mathrm{C}_{\mathrm{DOC}} \mathrm{dm}^{-3}$, it remains constant and equals $0.5 \mathrm{~m}$ (Fig. 2). High concentration of DOC increases the water turbidity and restricts the accessibility of light in the lake, consequently the photic zone gets significantly narrower and in deep littoral zones the light conditions deteriorate. This is one of the reasons for the withdrawal of deep-water plants including stoneworts, bryophytes and elodeids from the lakes (Rørslett and Johansen 1995; Middelboe and Markager 1997; Bociąg 2000; Szmeja 2000, 2003; Banaś 2001). 

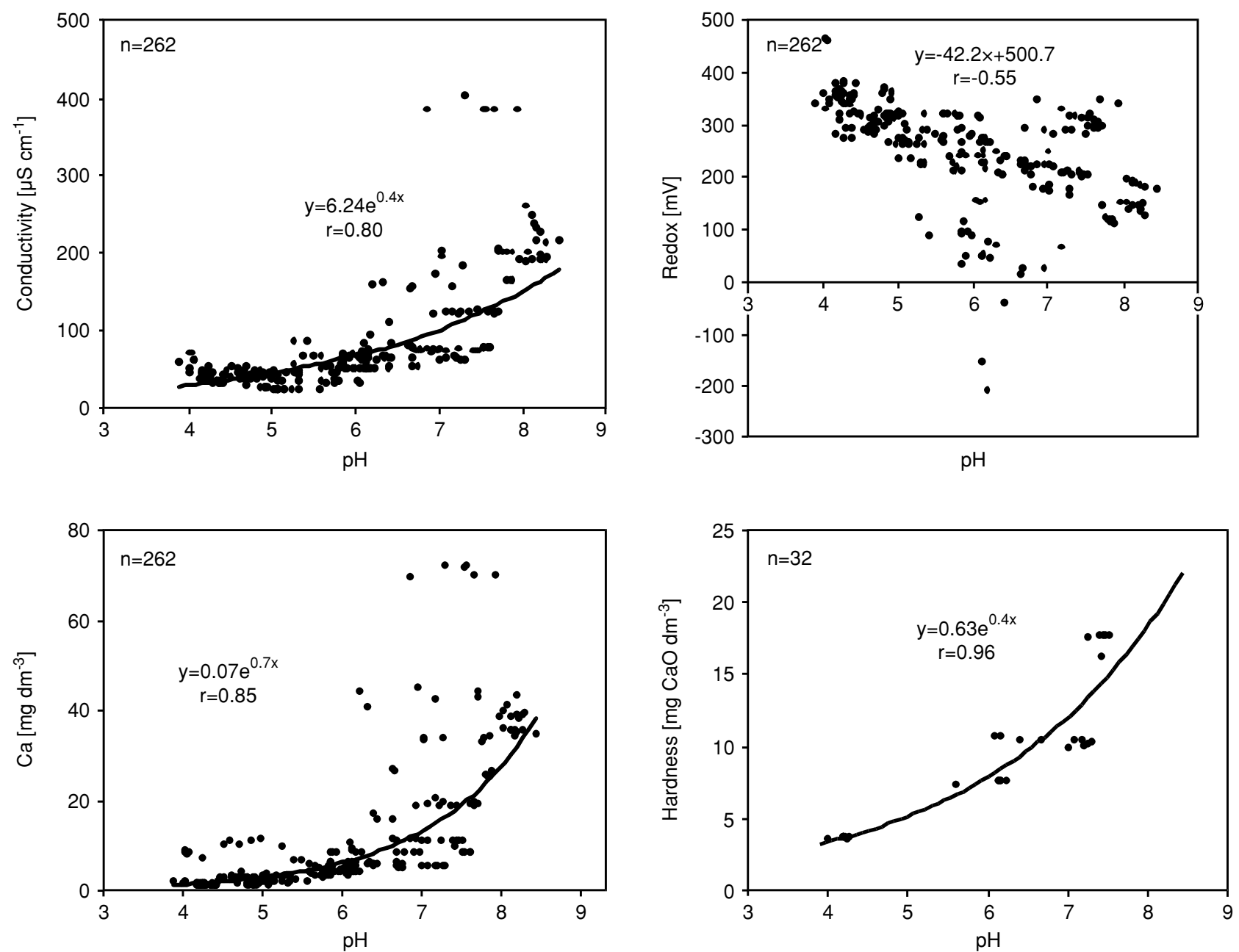

Fig. 1. Correlations between the lake water conductivity, redox potential, calcium concentration, hardness and the water $\mathrm{pH}$.

The correlations established for softwater lakes are stronger than those in hardwater ones, in the former strong correlations have been found between the DOC concentration and the water colour, visibility distance and $\mathrm{N}_{\mathrm{Kjel}}$. concentration, while in the latter - only between DOC concentration and the water colour. This is probably a consequence of a higher trophy of hard- than softwater lakes, and hence the higher concentrations of autochtonic DOC in the former.
The softwater lakes are usually small, without outflows, and localised in the surrounding of pine and mixed forests. This group includes e.g. lobelia lakes with vegetation composed mainly of isoetids and bryophytes (Szmeja 1996). Their bulk water is usually slightly acidic because of a low concentration of calcium (Szmeja et al. 1997). The environmental conditions in such water reservoirs have been mainly determined by external effects, including enrichment of

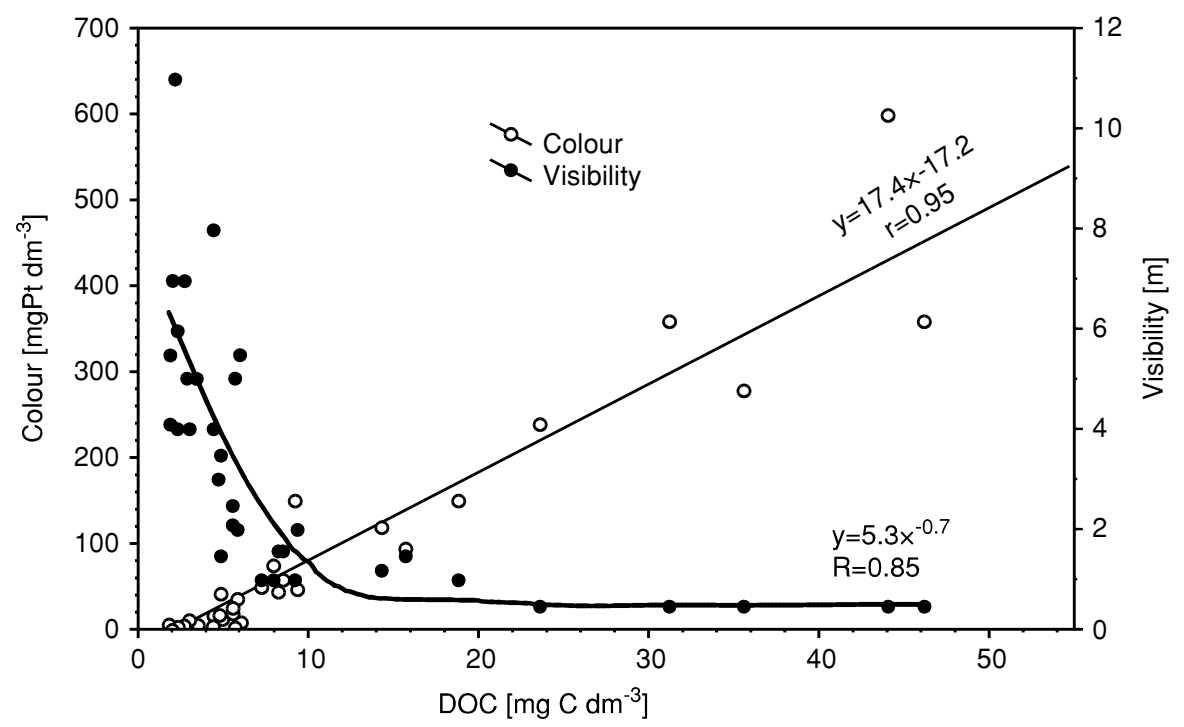

Fig. 2. The lake water colour or visibility distance as a function of DOC concentration. 
lakes with allochthonous organic matter. Of course the processes taking place in the lakes like e.g. succession - in particular the exchange of vascular plants by bryophytes, are also of importance (Szmeja 1994a; Gos et al. 1998).

The hardwater lakes are usually large, deep, with outflows and inflows, localised in the land with more fertile soil than the softwater ones. The water vegetation in such lakes is often dominated by Charales and elodeids (Bociąg 2000), the bulk water pH is neutral or basic with high contents of calcium and hydrocarbons, which means it is less susceptible to $\mathrm{pH}$ changes. A significant DOC concentration in hardwater lakes does not have to lead to a decrease in $\mathrm{pH}$ of the surface water, but leads to acidification of the near-sediment water. Despite a considerable supply of DOC, the hardwater lakes are still able to preserve their primary character (hardwater) and high $\mathrm{pH}$, on condition that the allochtonous hydrogen ions are neutralised by the carbonate complex. In the lakes without a constant supply of carbonates, the stock of mineral bases gets exhausted and the reservoir is more susceptible to changes. The $\mathrm{pH}$ value can decrease even to $\approx 5.5$ and undergo strong seasonal fluctuations. At present many of the Pomeranian lakes are at this stage of transformation of the environmental conditions (Banaś and Gos 1998, 2000; Szmeja et al. 1997a, 1998). On continuous and considerable supply of DOC, the water $\mathrm{pH}$ can drop to highly acidic and stabilise at $\mathrm{pH} \approx 4.5$. Some lakes, especially those localised in the forests undergo further acidification, their $\mathrm{pH}$ values decrease below $\mathrm{pH} 4.5$ that is typical of highmoor water (Banaś and Gos 2004). It should be emphasised that even a small drop of $\mathrm{pH}$ value leads to elimination of stoneworts being the main group of plants in hardwater lakes (Bociąg 2000; Szmeja 2000).

The stability of organic carbon compounds is different in hard- and softwater lakes. In the former they are quicker bound and quicker released, which follows from the presence of a larger number of components, especially mineral, which can bound them (Johnson et al. 1994; Ward et al. 1994). Thanks to these processes, organic carbon species enter into sediments and their concentration in the bulk water decreases. Nevertheless, on continuous supply of DOC, its concentration is still high. As a consequence, not only the physical and chemical properties of the lake water change, but also their bottom sediment layer gets richer in organic matter including humic and fulvic acids, nitrogen and phosphorus compounds (Banaś 2004).

\section{ACKNOWLEDGEMENTS}

Financial support of the Committee for Scientific Research within the projects KBN 6P04G $027 \quad 15$ and 3P04G 06224 is gratefully acknowledged. My sincere thanks go to Prof. Józef Szmeja for kind supervision. I also wish to thank my colleagues from the Department of Plant Ecology for help in the field and laboratory work.

\section{LITERATURE CITED}

ARTINGER R., BUCKAU G., GEYER S., FRITZ P., WOLF M., KIM J.I. 2000. Characterization of groundwater humic substances: influence of sedimentary organic carbon. Applied Geochemistry 15: 97-116.
ARTS G.H.P. 1987. Historical development and extent of acidification of shallow soft waters in the Netherlands, p. 928-933. In: P. Mathy (ed.) Air pollution and ecosystems. Proc. Int. Symp., Grenoble 1987.

BANAŚ K. 1999. Osuszanie siedlisk organogenicznych a funkcjonowanie ekosystemów jeziornych (Drainage of the organogenic habitats and functioning of lake ecosystms). p. 191-199. In: A. Barcikowski, M. Boiński, A. Nienartowicz (eds). Wielofunkcyjna rola lasu, ochrona przyrody, gospodarka, edukacja. O. W. Turpress, Torun, 264 pp. (in Polish with English summary)

BANAŚ K. 2001. Wpływ substancji humusowych na warunki siedliskowe roślin podwodnych. Uniwersytet Gdański, Mscr. 130 pp. (in Polish)

BANAŚ K. 2002. Impact of humic substances on Sphagnum denticulatum Bridel habitats. Acta Soc. Bot. Pol. 1: 63-69.

BANAŚ K. 2004. Impact of dissolved organic carbon on macrophytes environmental conditions in the lakes. Physical and chemical characteristics of the sediment (in press).

BANAŚ K., GOS K. 1998. Transformacja roślinności podwodnej w procesie acydyfikacji jezior oligotroficznych na Pomorzu (Transformation of submerged vegetation in the process of acidification of oligotrophic lakes in Pomerania). In: W. Lange and D. Borowiak (eds) Zagrożenia degradacyjne a ochrona jezior (Degradation hazards and lakes' protection). Wyd. DJ, Gdańsk, 161-171. (in Polish with English summary)

BANAŚ K., GOS K. 2000. Succession trends of submerged vegetation in Pomeranian acidic lakes (NW Poland). Acta Hyrobiol. 41: 171-178.

BANAŚ K., GOS K. 2004. Effect of peat-bog reclamation on the physico-chemical characteristics of the ground water in peat. Pol. J. Ecol., 52 (1): 313-318.

BOCIĄG K. 2000. Transformacja roślinności podwodnej w procesie humizacji jezior. Uniwersytet Gdański, Mscr. 167 pp. (in Polish)

BOCIĄG K., SZMEJA J. 2001. Degeneration of the vegetation of softwater lakes under the influence of humic substances. Ekol. Pol. 49 (4): 309-328.

COLLIER K.J. 1987. Spectral properties of some West Coast waters and their relationship with dissolved organic carbon. Mauri Ora 14.

FORSBERG C. 1992. Will an increased greenhouse impact in Fennoscandia give rise to more humic and coloured lakes? Hydrobiologia 229: 51-58.

GOS K., BOCIĄG K., BANAŚ K. 1998. Roślinność podwodna w kwaśnych jeziorach Pomorza (Submerged vegetation in the acid lakes of Pomerania). In: J. Banaszak and K. Tobolski (eds) Park Narodowy Bory Tucholskie. Wyd. WSP Bydgoszcz, 261-277. (in Polish with English summary)

GÓRNIAK A. 1995. Spektrofotometryczna metoda oznaczania stężeń i jakości rozpuszczonego węgla organicznego w wodach. Gosp. Wodna, 2: 31-33. (in Polish)

GÓRNIAK A. 1996. Substancje humusowe i ich rola w funkcjonowaniu ekosystemów słodkowodnych. Dział Wydawnictw Filii UW w Białymstoku, Białystok, 151 pp. (in Polish)

GRAHN O. 1985. Macrophyte biomass and production in Lake Gárdsjön - an acidified clearwater lake in SW Sweden. Ecol. Bull. 37: 203-221.

HAYS W.L. 1988. Statistics (3rd ed.). New York: CBS College Publishing.

HERMANOWICZ W., DOŻAŃSKA W., DOJLIDO J., KOZIOROWSKI B. 1999. Fizyczno-chemiczne badanie wody i ścieków. Warszawa, 847 pp. (in Polish)

HESSEN D.O., TRANVIK L.J. 1998. Aquatic Humic Substances. Ecological Studies, Springer-Verlag, Berlin Heidelberg, vol. 133.

JOHNSON B.D., KRANCK K., MUSCHENHEIM D.K. 1994. Physico-chemical factors in particle aggregation, p. 75-96. In: R.S. Wotton (ed.), The biology of particles in aquatic systems. Lewis Publishers, Boca Raton. 
JONSSON A., JONSSON M. 1997. Sedimentation and mineralization of organic carbon, nitrogen and phosphorus in a large humic lake, northern Sweden. Arch. Hydrobiol. 141 (1): 45-65.

KAPLAN L.A., NEWBOLD J.D. 1993. Biogeochemistry of dissolved organic carbon entering streams, p. 139-166. In: T.E. Ford (ed.), Aquatic microbiology. An Ecological Approach. Blackwell Scientific Publications, Oxford.

KESKITALOK J., ELORANTA P. 1999. Limnology of Humic Waters. Backhuys Publishers, Leiden, VIII und 292.

LAAKSONEN R., MALIN V. 1984. Changes in ionic distributions in Finnish lake water during the period 1968-1983. Publ. Wat. Res. Inst. National Board of Waters, Helsinki 57: 59-60.

LÅNGVIK V., ÅKERBACK N., HOLMBOM B. 1994. Characterization of aromatic structures in humic and fulvic acids. Environ. Int. 20: 61-65.

LAMPERT W., SOMMER U. 1996. Ekologia wód śródlądowych. Wyd. Nauk. PWN, Warszawa.

LEHTONEN T., PEURAVUORI J., PIHLAJA K. 2000. Characterisation of lake-aquatic humic matter isolated with two different sorbing solid techniques: tetramethylammonium hydroxide treatment and pyrolysis-gas chromatography/mass spectrometry. Analytica Chimica Acta 424: 91-103.

MIDDELBOE A.L., MARKAGER S. 1997. Depth limits and minimum light requirements of freshwater macrophytes. Freshwater Biology 37: 553-568.

MILLIKEN G.A. JOHNSON D.E. 1984. Analysis of messy data: Vol. I. Designed experiments. Van Nostrand Reinhold, Co. New York.

MOORE T.R. 1985. The spectrophotometric determination of dissolved organic carbon in peat waters. Soil Sci. Soc. Ann. J. 49: 1590-1592.

MOORE T.R. 1987. An assessment of a simple spectrophotometric method for the determination of dissolved organic carbon in freshwaters. New Zeal. J. Mar. Fresh. Res. 21: 585-589.

MORRIS D.P., HARGREAVES B.R. 1997. The role of photochemical degradation of dissolved organic carbon in regulating the UV transparency of three lakes on the Pocono Plateau. Limnol. Oceanogr. 42: 239-249.

OKTABA W. 1980. Elementy statystyki matematycznej i metodyka doświadczalna. Wyd. Nauk. PWN, Warszawa. (in Polish)

OLIVER B.G., THURMAN E.M., MALCOLM R.L. 1983. The contribution of humic substances to the acidity of colored natural waters. Geochimica et Cosmochimica Acta 47: 2031-2035.

ROELOFS J.G.M. 1983. Impact of acidification and eutrophication on macrophyte communities in soft waters in the Netherlands. I. Field observations. Aquatic Botany 17: 139-155.

ROGALLA J.A. 1986. Empirical acidification modeling for lakes in the upper Great Lakes region. M.S. thesis, Univ. of Minn., Minneapolis.

RØRSLETT B., JOHANSEN S.W. 1995. Dynamic response of submerged macrophyte, Isoëtes lacustris, to alternating light levels under field conditions. Aquatic Botany 51: 223-242.
SAND-JENSEN K. 1989. Environmental variables and their effect on photosynthesis of aquatic plant communities. Aquatic Botany 34: 5-25.

SCHINDLER D.W., BAYLEY S.E., CURTIS P.J., PARKER B.R., STAINTON M.P., KELLY C.A. 1992. Natural and mancaused factors affecting the abundance and cycling of dissolved organic substances in precambrian shield lakes. Hydrobiologia 229: 1-21.

STEVENSON F.J. 1982. Humus Chemistry. John Wiley \&. Sons, New York.

SZMEJA J. 1992. Struktura, organizacja przestrzenna i demografia populacji isoetydów (Structure, Spatial organization and demography of isoetid populations). Wyd. UG, Rozprawy i monografie 175: 1-137. (in Polish with English summary)

SZMEJA J. 1994a. An individual's status in populations of isoetid species. Aquatic Botany 48: 203-224.

SZMEJA J. 1994b. Effect of disturbances and interspecific competition in isoetid populations. Aquatic Botany 48: 225-238.

SZMEJA J. 1994c. Dynamics of the abundance and spatial organization of isoetid populations in an oligotrophic lake. Aquatic Botany 49: 19-32.

SZMEJA J. 1996. Rejestr polskich jezior lobeliowych (Register of Polish Lobelia lakes). Fragm. Flor. Geobot., Ser. Pol. 3: 347-367. (in Polish with English summary)

SZMEJA J. 2000. Tendences of changes in the flora and vegetation structure of Pomeranian lakes under the influence of humic substances. 85-98. In: B. Jackowiak, W. Żukowski (eds), Mechanisms of anthropogenic changes of the plant cover. Bogucki Wyd. Naukowe, Poznań.

SZMEJA J. 2003. Przewodnik do badań roślinności jezior. Wyd. Nauk. PWN (in press).

SZMEJA J., BANAŚ K., BOCIĄG K. 1997. Ecological conditions and tolerance limits of isoetids along the southern Baltic coast. Ekol. Pol., 45, 2, 343-359.

SZMEJA J., BOCIĄG K. BANAŚ K. 1998. Specyfika jezior lobeliowych w krajobrazie sandrowym Borów Tucholskich (The specificity of lobelian lakes in the outwash plant lakndscape of Bory Tucholskie). p 171-192, In: K. Tobolski, J. Banaszak (eds), Park Narodowy Bory Tucholskie. WSP Bydgoszcz, Bydgoszcz, 486 pp. (in Polish with English summary)

TIPPING E., HILTON J., JAMES B. 1988. Dissolved organic matter in Cumbrian lakes and streams. Freshwater Biology 19: 371-378.

WARD G.M., WARD A.K., DAHM C.N., AUMEN N.C. 1994. Origin and formation of organic and inorganic particles in aquatic systems, p. 45-73. In: R.S. Wotton (ed.), The biology of particles in aquatic systems. Lewis Publishers, Boca Raton.

YAN L., STALLARD R.F. KEY R.M., CRERAR D.A. 1991. Trace metals and dissolved organic carbon in estuaries and offshore waters of New Jersey, USA. Geochimica et Cosmochimica Acta 55: 3647-3656. 